\title{
A prostacyclin analogue, iloprost, protects from bleomycin-induced pulmonary fibrosis in mice
}

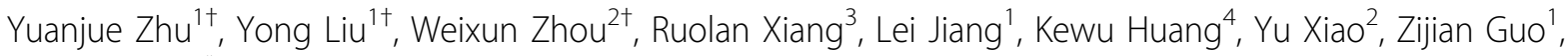 \\ Jinming Gao ${ }^{1 *}$
}

\begin{abstract}
Background: Metabolites of arachidonic acid such as prostacyclin $\left(\left.P G\right|_{2}\right)$ have been shown to participate in the pathogenesis of pulmonary fibrosis by inhibiting the expression of pro-inflammatory and pro-fibrotic mediators. In this investigation, we examined whether iloprost, a stable $\mathrm{PGI}_{2}$ analogue, could prevent bleomycin-induced pulmonary inflammation and fibrosis in a mouse model.

Methods: Mice received a single intratracheal injection of bleomycin with or without intraperitoneal iloprost. Pulmonary inflammation and fibrosis were analysed by histological evaluation, cellular composition of bronchoalveolar lavage (BAL) fluid, and hydroxyproline content. Lung mechanics were measured. We also analysed the expression of inflammatory mediators in BAL fluid and lung tissue.

Results: Administration of iloprost significantly improved survival rate and reduced weight loss in the mice induced by bleomycin. The severe inflammatory response and fibrotic changes were significantly attenuated in the mice treated with iloprost as shown by reduction in infiltration of inflammatory cells into the airways and pulmonary parenchyma, diminution in interstitial collagen deposition, and lung hydroxyproline content. lloprost significantly improved lung static compliance and tissue elastance. It increased the expression of IFNy and CXCL10 in lung tissue measured by RT-PCR and their levels in BAL fluid as measured by ELISA. Levels of TNF $\alpha, I L-6$ and TGF $\beta 1$ were lowered by iloprost.
\end{abstract}

Conclusions: Iloprost prevents bleomycin-induced pulmonary fibrosis, possibly by upregulating antifibrotic mediators (IFN $\gamma$ and CXCL10) and downregulating pro-inflammatory and pro-fibrotic cytokines (TNF $\alpha$, IL-6, and TGF $\beta 1$ ). Prostacyclin may represent a novel pharmacological agent for treating pulmonary fibrotic diseases.

\section{Introduction}

Idiopathic pulmonary fibrosis (IPF) is a progressively fatal disorder characterized by inflammatory alveolitis and scarring in the pulmonary interstitium with loss of lung function; it is estimated that there is a 70\% mortality within 5 years from initial diagnosis [1]. The current pharmacologic therapy for IPF is limited and there are no effective treatments [1]. The mechanisms underlying the pathogenesis of IPF include the accumulation of inflammatory cells in the lungs, and the generation of pro-inflammatory and pro-fibrotic mediators, resulting in alveolar epithelial cell injury and fibroblast

\footnotetext{
* Correspondence: gaojm@pumch.cn

† Contributed equally

'Department of Respiratory Diseases, Peking Union Medical College Hospital, Chinese Academy of Medical Sciences \& Peking Union Medical College, Beijing 100730, China
}

(c) 2010 Zhu et al; licensee BioMed Central Ltd. This is an Open Access article distributed under the terms of the Creative Commons Attribution License (http://creativecommons.org/licenses/by/2.0), which permits unrestricted use, distribution, and reproduction in any medium, provided the original work is properly cited. hyperplasia, and eventually excessive deposition of extracellular collagen [2]. Searching for new agents to meet this unmet medical need is a priority.

There is accumulating evidence that bioactive metabolites of arachidoic acid (eicosanoids) may either contribute to or protect against lung fibrosis. Eicosanoids may regulate the fibroproliferative response directly through an action on lung resident cells and/or indirectly through modulating recruitment of inflammatory cells, release of mediators, and intracellular signaling pathways [3]. Leukotriene (LT) $\mathrm{B}_{4}$, a metabolite synthesized by 5lipoxygenase (5-LO), was elevated in bronchoalveolar (BAL) fluid of patients with IPF [4] and deletion of 5-LO leading to a deficiency in sulphidopeptide-leukotriene production ameliorated bleomycin-induced fibrosis in mice [5]. In addition, antagonizing $\mathrm{LTB}_{4}$ receptor attenuated the lung fibrosis induced by bleomycin in 
mice by suppressing the production of inflammatory and fibrotic cytokines and by promoting the antifibrotic cytokine, IFN $\gamma[6]$.

In contrast to $\mathrm{LTB}_{4}$, prostaglandin (PG) $\mathrm{E}_{2}$ generated by cyclooxygenase (COX)-2 pathway inhibited lung fibrosis by suppressing fibroblast proliferation and collagen synthesis [7]. The preventive and therapeutic effects of the administration of a $\mathrm{PGE}_{2}$ synthetic compound on lung fibrosis induced by bleomycin through anti-inflammatory mechanisms has been recently demonstrated [8].

$\mathrm{PGI}_{2}$, known as prostacyclin, is produced through the action of COX-2 and a membrane-anchored prostacyclin synthase and is secreted by alveolar type II cells in large quantities [9]. By specifically binding to a single Gprotein coupled receptor (IP), $\mathrm{PGI}_{2}$ induces anti-inflammatory and anti-fibroproliferative activity through elevating intracellular cyclic adenosine monophosphate (cAMP) [9]. A decreased level of $\mathrm{PGI}_{2}$ was found in fibroblasts isolated from IPF patients [10]. $\mathrm{PGI}_{2}$ has been shown to inhibit migration, proliferation and collagen synthesis of fibroblasts in vitro[11,12]. Mice lacking COX-2-derived $\mathrm{PGI}_{2}$ or IP were more susceptible to developing severe pulmonary fibrosis in response to bleomycin than wild type mice in a $\mathrm{PGE}_{2}$-independent fashion [13]. Additionally, a synthetic prostacyclin agonist attenuated bleomycin-induced lung fibrosis in mice [14]. Besides, inhalation of a stable $\mathrm{PGI}_{2}$ analogue, iloprost, was shown to abrogate the allergic inflammation in animal model of asthma [15].

$\mathrm{PGI}_{2}$ may inhibit the development of lung fibrosis by controlling inflammation and fibrosis [9]. The aim of this study was to investigate the role of $\mathrm{PGI}_{2}$ by using intraperitoneal administration of iloprost in a mouse model of bleomycin-induced pulmonary fibrosis and the possible mechanism(s) by which $\mathrm{PGI}_{2}$ might mediate its effect.

\section{Materials and methods}

\section{Mice and bleomycin injection}

Mice with C57BL/6 background (6 to 8-week old; 20-25 g body weight) were maintained in a pathogen-free mouse facility. All experiments were performed according to international and institutional guidelines for animal care and were approved by the Animal Ethics Committee of Peking Union Medical College Hospital. Clean food and water were supplied with free access.

The adult male mice were anesthetized with pentobarbital intraperitoneally, followed by a single intratracheal injection of $3 \mathrm{mg} / \mathrm{kg}$ of bleomycin sulfate (Nippon Kayaku, Japan) in $50 \mu$ l of sterile phosphate-buffered saline (PBS). Control mice were injected with $50 \mu \mathrm{l}$ of sterile PBS. In some experiments examining lung mechanics and cellular and biochemical characterization of BAL fluid, we used a smaller dose of bleomycin $(2 \mathrm{mg} / \mathrm{kg}$ body weight) in order to avoid significant mortality.

Iloprost (200 $\mu \mathrm{g} / \mathrm{kg}$; Schering, Berlimed, Spain) dissolved in $500 \mu \mathrm{l}$ of PBS was intraperitoneally administered 10-15 minutes prior to intratracheal injection of bleomycin. In some experiments, iloprost was given intraperitoneally 7 days after bleomycin treatment. The dosage of iloprost adopted in this investigation was optimized based on the series of preliminary studies, in which we found no effectiveness at the lower doses of iloprost of 100 and $150 \mu \mathrm{g} / \mathrm{kg}$.

The mice were randomly allocated into four groups: 1 . PBS (PBS) alone; 2. PBS+iloprost; 3. bleomycin; 4. bleomycin (Bleo)+iloprost.

\section{Histopathological evaluation of pulmonary fibrosis}

On day 14 post-administration, animals were sacrificed by overdosage of pentobarbital and perfused via the left ventricle with $5 \mathrm{ml}$ of cold saline. The lungs were carefully removed, inflated to $25 \mathrm{cmH}_{2} \mathrm{O}$ with $10 \%$ formalin and fixed overnight, embedded in paraffin, and sectioned at $5 \mu \mathrm{M}$ thickness. The sections were stained with Hematoxylin \& Eosin for routine histology or with Masson trichrome for mature collagen.

Histopathological scoring of pulmonary fibrosis was performed as described by Ashcroft and co-workers [16]. The severity of fibrotic changes in each lung section was assessed as a mean score of severity. At least 10 high-power fields within each lung section were evaluated.

Alveolar septal thickening was quantified using digital imaging as previously described [17]. Briefly, at least five images of representative areas of each lung lobe stained with hematoxylin and eosin were randomly captured and analyzed for alveolar thickening, accumulation of leukocytes, and increased extracellular matrix and fibroblasts. With NanoZoomer Digital Pathology C9600 (Hamamatsu Photonics K.K., Japan), threshold was defined as the areas containing thickened septum of digital images which were automatically counted by the system. Then the threshold areas were divided by the total areas of the selected images and multiplied by 100 to generate a percentage of the thickened area in each mouse.

The pathological analysis was independently performed for each mouse in a blind manner by two experienced pathologists.

\section{Assessment of lung mechanics}

On day 21 after treatment, mice were prepared as previously described for invasive analysis of lung mechanics using a computer-controlled small animal ventilator, the Flexivent system (Scireq, Montreal, PQ, Canada) $[13,18,19]$. Briefly, mice were mechanically ventilated at 
a rate of 150 breaths $/ \mathrm{min}$, tidal volume of $10 \mathrm{ml} / \mathrm{kg}$, and a positive end-expiratory pressure of $3 \mathrm{cmH}_{2} \mathrm{O}$. We documented the tracheal pressure (Ptr), volume (V), and airflow. Pressure-volume curves were generated after delivering incremental air into lungs from functional residual to total lung capacity. Static compliance (Cst), reflecting elastic recoil of the lungs, was calculated by the Flexivent software using Salazar-Knowles equation. Tissue elastance $(\mathrm{H})$ was measured by forced oscillation technique using Flexivent software.

\section{Bronchoalveolar lavage fluid}

Bronchoalveolar lavage (BAL) fluid was conducted as previously described [20]. Briefly, mice were sacrificed 14 days later, and the trachea was cannulated by using 20 -gauge catheter. BAL was performed three times with $0.8 \mathrm{ml}$ of ice-cold PBS (PH 7.4) with $90 \%$ of recovery rate. The BAL fluid was spun, supernatant was collected and kept at $-70^{\circ} \mathrm{C}$ until used. Recovered total cells were counted on a hemocytometer in the presence of $0.4 \%$ trypan blue (Sigma, MO). For differential cell counting, cells were spun onto glass slides, air-dried, fixed, and routinely stained. The number of macrophages, neutrophils and lymphocytes in 200 cells was counted based on morphology.

\section{Hydroxyproline assay}

Total lung collagen was determined by analysis of hydroxyproline as previously described [21]. Briefly, lungs were harvested 14 days after treatment and homogenized in $\mathrm{PBS}$ (PH 7.4), digested with $12 \mathrm{~N} \mathrm{HCl}$ at $120^{\circ}$ $\mathrm{C}$ overnight. Citrate/acetate buffer ( $\mathrm{PH}$ 6.0) and chloramine- $T$ solution were added at room temperature for 20 minutes and the samples were incubated with Ehrlich's solution for $15 \mathrm{~min}$ at $65^{\circ} \mathrm{C}$. Samples were cooled to room temperature and read at $550 \mathrm{~nm}$. Hydroxyproline standards (Sigma, MO) at concentrations between 0 to $100 \mu \mathrm{g} / \mathrm{ml}$ were used to construct a standard curve.

\section{RT-PCR analysis for mRNA expression of cytokines andchemokines}

Total RNA was extracted from the lung using TRIzol reagent (Invitrogen, CA) according to manufacturer's instructions, and treated with RNase-free DNase. RNA was reverse-transcribed into cDNA using $\mathrm{M}-\mathrm{MuLV}$ reverse transcriptase (Invitrogen). Then $1 \mu \mathrm{l}$ of cDNA was subjected to PCR in a $25 \mu$ l final reaction volume for analysing the expression of CXCL10/IP-10, IL-6, TGF $\beta 1$, and TNF $\alpha$. $\beta$-actin was analysed as an internal control. The amplification conditions were as follows: initial step at $95^{\circ} \mathrm{C}$ for $10 \mathrm{~min}$, followed by 35 cycles of $95^{\circ} \mathrm{C}$ for $1 \mathrm{~min}, 55^{\circ} \mathrm{C}$ for $1 \mathrm{~min}$ and $72^{\circ} \mathrm{C}$ for $1 \mathrm{~min}$. The primers and products of RT-PCR are presented in Table 1.
Table 1 RT-PCR primers and products

\begin{tabular}{llll}
\hline Genes & S/AS & Primer sequence (5' to $\mathbf{3}^{\prime}$ ) & Products (bp) \\
\hline CXCL10 & S & GTCATTITCTGCCTCATCC & 273 \\
& AS & GAGCCCTTTAGACCTTT & \\
IL-6 & S & TGGGACTGATGCTGGTGA & 376 \\
& AS & CTGGCTTTGTCTTCTTGTTATC & \\
TGF $\beta 1$ & S & CCCTGTATTCCGTCTCCT & 363 \\
& AS & GCGGTGCTCGCTTGTA & \\
TNF $\alpha$ & S & GGCGGTGCCTATGTCTC & 383 \\
& AS & GCAGCCTTGTCCCTTGA & \\
$\beta$-actin & S & CTCCTTAATTCACGCACGATTC & 541 \\
& AS & GTGGGGCGCCCAGGCACCA & \\
\hline
\end{tabular}

S, sense; AS, antisense

\section{Analysis of cytokines, chemokines, and eicosanoids in BALF}

The concentrations of IFN $\gamma$, IL-6, TGF $\beta 1$, and CXCL10/ IP-10 in BAL fluid were determined by ELISA. The ELISA kits for IFN $\gamma$ and CXCL10/IP-10 were purchased from R\&D systems, the kits for IL- 6 and TGF $\beta 1$ were products of Amersham Bioscience. The detection limits of IFN $\gamma$, IL-6, TGF $\beta 1$, and CXCL10/IP-10 were 4, 4, 60, and $2.2 \mathrm{pg} / \mathrm{ml}$, respectively.

The levels of $\mathrm{LTB}_{4}$ and $\mathrm{PGE}_{2}$ were quantified using enzyme immunoassay (EIA) kits (Cayman chemical, $\mathrm{MI})$. The detection limits for $\mathrm{LTB}_{4}$ and $\mathrm{PGE}_{2}$ were 15.3 $\mathrm{pg} / \mathrm{ml}$ and $15.5 \mathrm{pg} / \mathrm{ml}$, respectively.

\section{Statistics}

Data are expressed as means \pm SEM. Comparisons were carried out using ANOVA followed by unpaired Student's $t$ test. Survival curves (Kaplan-Meier plots) were compared using a log rank test (Graph Pad Software Inc., San Diego, CA). A value of $P$ less than 0.05 was considered significant.

\section{Results}

Effect of iloprost on survival rate and body weight loss

To demonstrate the protective effect of $\mathrm{PGI}_{2}$ on bleomycin-induced pulmonary injury, the mice were intraperitoneally administered with or without iloprost prior to injection of bleomycin at a dose of $3 \mathrm{mg} / \mathrm{kg}$. The mice treated with bleomycin (but not receiving iloprost) began to die at day 9 . Cumulative mortality was $60 \%$ at day 21 ; by contrast, mortality of mice treated with bleomycin + iloprost was significantly lower $(10 \%$ at day $21, \mathrm{P}<$ 0.0001) (Figure 1A). A protective effect of iloprost was also observed on weight loss. The mice treated with bleomycin (but not receiving iloprost) lost more weight than the mice treated with bleomycin+iloprost (Figure 1B).

\section{Effect of iloprost on bleomycin-induced pulmonary inflammation and fibrosis}

The effect of iloprost against bleomycin-induced fibrosis and inflammation was examined. Animals were 


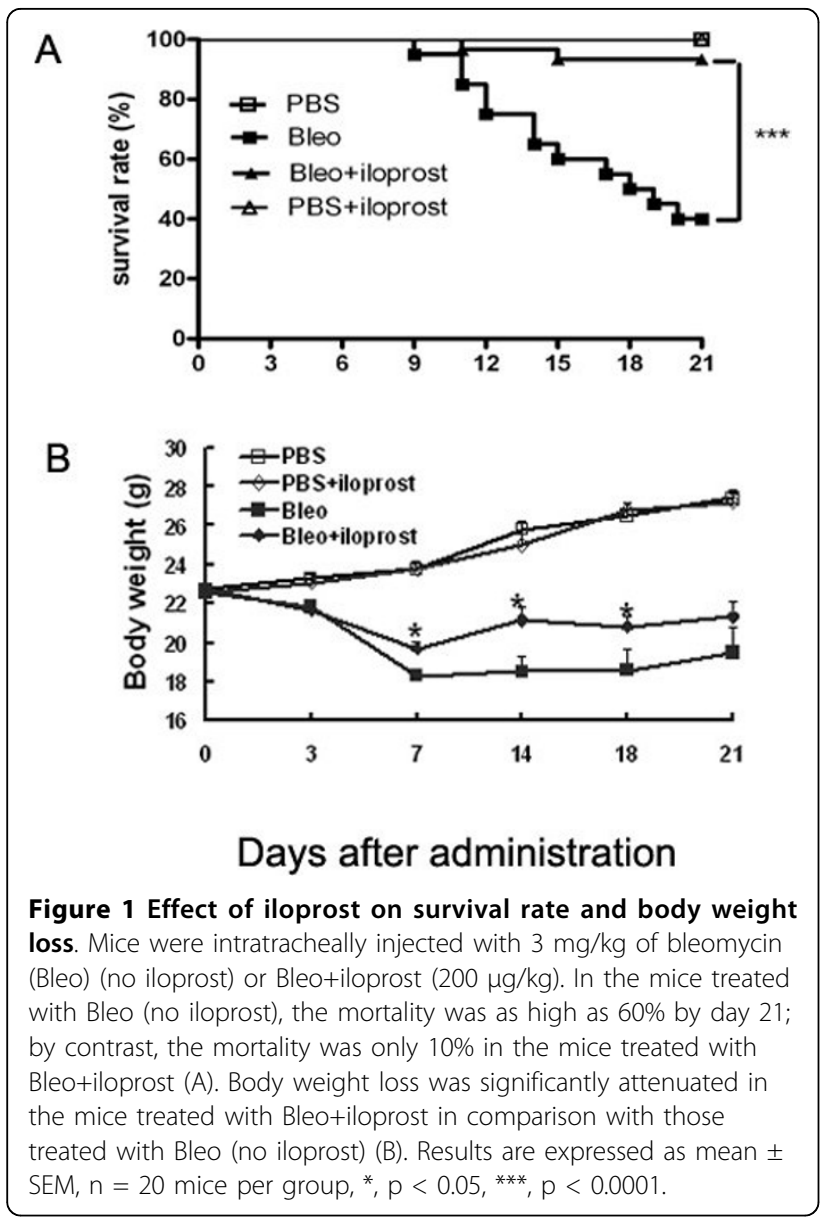

sacrificed at day 14 after treatment and the lung sections were analyzed for the severity of inflammation and fibrosis. As shown in Figure 2, normal alveolar structure was seen in PBS-treated mice and PBS+iloprost-treated mice (A and B). Figure 2 shows representative lung histology at day 14 post-bleomycin installation. Mice treated with bleomycin (no iloprost) had more severe and extensive inflammation and fibrosis and more obvious alveolar wall thickening, distorted pulmonary architecture, massive infiltration of leukocytes and excessive deposition of mature collagen in interstitium (C and $E)$, compared with the mice administered with bleomycin +iloprost (D and F).

We measured the thickened areas of alveolar septum relative to the total area of lung by digital imaging in at least five photographs of the lower lobes of lungs of the mice at day 14 post-treatment. PBS- or iloprost+PBStreated mice had normal alveolar septa, and all scored less than $1 \%$. The area of lungs with thickened alveolar septa treated with bleomycin (no iloprost) was 2.5 -fold greater than in the mice treated with iloprost+bleomycin $(56.1 \pm 4.1 \%$ vs $23.0 \pm 4.9 \%, \mathrm{P}=0.0004)$ (Figure $3 \mathrm{~A})$. There were significantly higher histopathologic scores in the mice treated with bleomycin (no iloprost) than in the mice treated with iloprost+bleomycin $(5.64 \pm 0.18$ vs $3.35 \pm 0.54, \mathrm{P}<0.0001$ ) (Figure 3B).

To quantitatively assess the difference in extent of pulmonary fibrosis in the bleomycin-treated mice with or without iloprost, we assayed the hydroxyproline content unique to mature collagen in the lung tissue. The amount of hydroxyproline was significantly greater in bleomycin-treated mice than in iloprost+bleomycin treated-mice $(90.29 \pm 6.25$ vs $67.84 \pm 1.88 \mu \mathrm{g} /$ left lung, $\mathrm{P}=$ 0.02) (Figure 3C).

\section{Effect of iloprost on infiltration of the inflammatory cells in airways}

To determine whether iloprost affects bleomycininduced infiltration of inflammatory cells into the airways, we estimated the cell populations in BAL fluid differentially 3,7 , and 14 days after bleomycin treatment. At day 7, the number of total inflammatory cells in BAL fluid was significantly less in the mice administrated with iloprost+bleomycin than those treated with bleomycin (no iloprost) $\left(102.4 \pm 14.9 \times 10^{4}\right.$ vs $194.8 \pm 9.0 \times$ $10^{4}, \mathrm{P}<0.01$ ) (Figure $4 \mathrm{~A}$ ). At day 14, the total cells were marginally fewer in the mice treated with iloprost +bleomycin than those treated with bleomycin (no iloprost) $\left(60.5 \pm 6.2 \times 10^{4}\right.$ vs $\left.132.0 \pm 30.7 \times 10^{4}, \mathrm{P}=0.06\right)$.

As represented in Figure $4 \mathrm{~A}$, the peak cellular response occurred at day 7 after bleomycin injection. The predominant cell type was the lymphocyte and the number of lymphocytes, not neutrophils and macrophages, was significantly greater in the mice treated with bleomycin (no iloprost) than in those treated iloprost +bleomycin $\left(143.2 \pm 14.3 \times 10^{4}\right.$ vs $69.0 \pm 12.5 \times 10^{4}$; P $<0.01$ ) (Figure 4B-C).

\section{Effect of iloprost on alteration of lung mechanics}

We measured static compliance and tissue elastance in accordance with the previous studies showing a decrease in static compliance (Cst) and increase in tissue elastance $(\mathrm{H})$ in mice following bleomycin injury [13]. We found significant alterations of lung mechanics in mice treated with bleomycin (no iloprost), compared to control mice treated with PBS (no iloprost). However, decrease in Cst and increase in $\mathrm{H}$ were significantly attenuated in the mice treated with bleomycin+iloprost (for Cst: $0.014 \pm 0.002 \mathrm{ml} / \mathrm{cmH}_{2} \mathrm{O}$ vs $0.020 \pm 0.001 \mathrm{ml} /$ $\mathrm{cmH}_{2} \mathrm{O}, \mathrm{P}=0.01$; for $\mathrm{H}: 86.84 \pm 13.11 \mathrm{ml} / \mathrm{cmH}_{2} \mathrm{O}$ vs $49.96 \pm 1.83 \mathrm{ml} / \mathrm{cmH}_{2} \mathrm{O}, \mathrm{P}<0.01$ ) (Figure $5 \mathrm{~A}$ and $5 \mathrm{~B}$ ).

\section{Effect of iloprost on cytokines, chemokines and arachidonicacid products}

The level of TNF $\alpha$ mRNA was significantly lower in the mice treated with bleomycin+iloprost than the mice treated with bleomycin (no iloprost) (Figure 6A). IL-6 

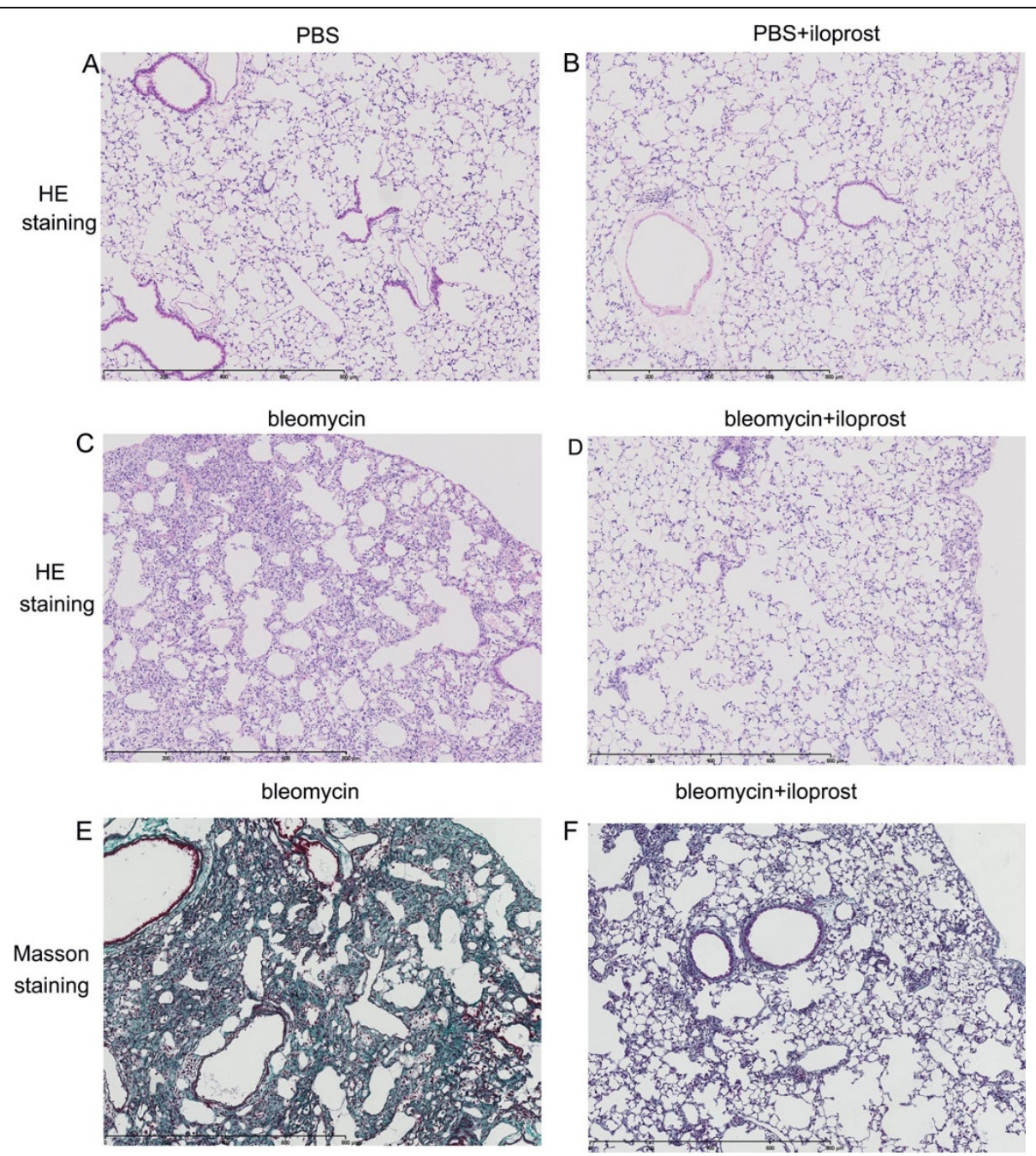

Figure 2 Effect of iloprost on bleomycin-induced pulmonary inflammation and fibrosis. Histological analysis of lungs in the mice treated with bleomycin and those treated with bleomycin+iloprost. Mice were killed at day 14 , lungs were removed, inflated with $1 \mathrm{ml}$ of $10 \%$ formalin. In the mice treated with PBS (no iloprost) or PBS+iloprost, there was normal alveolar structure (A and B). In the mice treated with bleomycin (no iloprost), there was more accumulation of leukocytes, distortion of alveolar architecture, and deposition of collagen ( $C$ and $E$ ), compared with the mice treated with bleomycin+iloprost (D and F). Panels A-D, H\&E staining; Panel E-F, Masson's trichrome staining.

mRNA expression was decreased at day 3 and significantly lowered by day 7 in the mice treated with iloprost+bleomycin (Figure 6B), while TGF $\beta 1$ mRNA was significantly inhibited at day 14 (Figure 6C). CXCL10/ IP-10 mRNA was significantly increased in lungs of the iloprost+bleomycin-treated mice by day $7(\mathrm{P}=0.03$ for day 3; $\mathrm{P}=0.02$ for day 7 ), and remained elevated at day 14 (Figure 6D).

ELISA assays determined that the level of IL-6 protein in BAL fluid was markedly elevated 3 days after bleomycin administration (no iloprost), but was significantly lower in mice treated with bleomycin+iloprost $(131.5 \pm 38.2 \mathrm{pg} / \mathrm{ml}$ vs $26.5 \pm 4.0 \mathrm{pg} / \mathrm{ml}, \mathrm{P}=0.02)$ (Figure 6E). The concentration of IFN $\gamma$ in BAL fluid was significantly higher at day 3 and remained elevated at day 7 in the mice treated with bleomycin+iloprost, compared with the mice treated with bleomycin (no iloprost) (at day 3: $59.3 \mathrm{pg} / \mathrm{ml} \pm 10.5 \mathrm{pg} / \mathrm{ml}$ vs $18.9 \pm$ $9.8 \mathrm{pg} / \mathrm{ml}, \mathrm{P}=0.02$; at day $7: 41.0 \pm 8.8 \mathrm{pg} / \mathrm{ml}$ vs 21.7 $\pm 2.5 \mathrm{pg} / \mathrm{ml}, \mathrm{P}=0.06$ ) (Figure $6 \mathrm{~F}$ ). The concentration of TGF $\beta 1$ was significantly higher in BAL fluid recovered from the mice treated with bleomycin (no iloprost) than from the mice treated with iloprost +bleomycin at day14 $(14350 \pm 4798 \mathrm{pg} / \mathrm{ml}$ vs $1906 \pm$ $990 \mathrm{pg} / \mathrm{ml}, \mathrm{P}<0.01$ ) (Figure 6G). The concentration of IFN $\gamma$-inducible CXCL10 in BAL fluid was markedly higher in the mice treated with bleomycin+iloprost than those treated with bleomycin (no iloprost) at day $14(108.4 \pm 5.5$ vs $65.9 \pm 6.4 \mathrm{pg} / \mathrm{ml}, \mathrm{P}=0.001)$ (Figure 6H). 


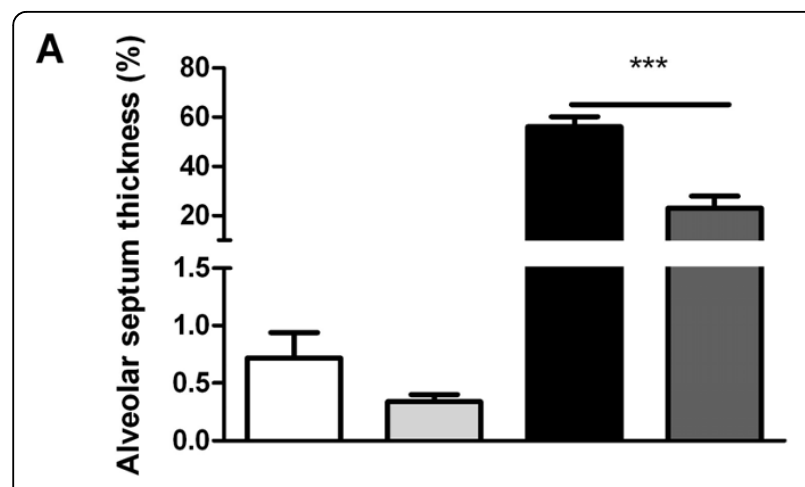

B
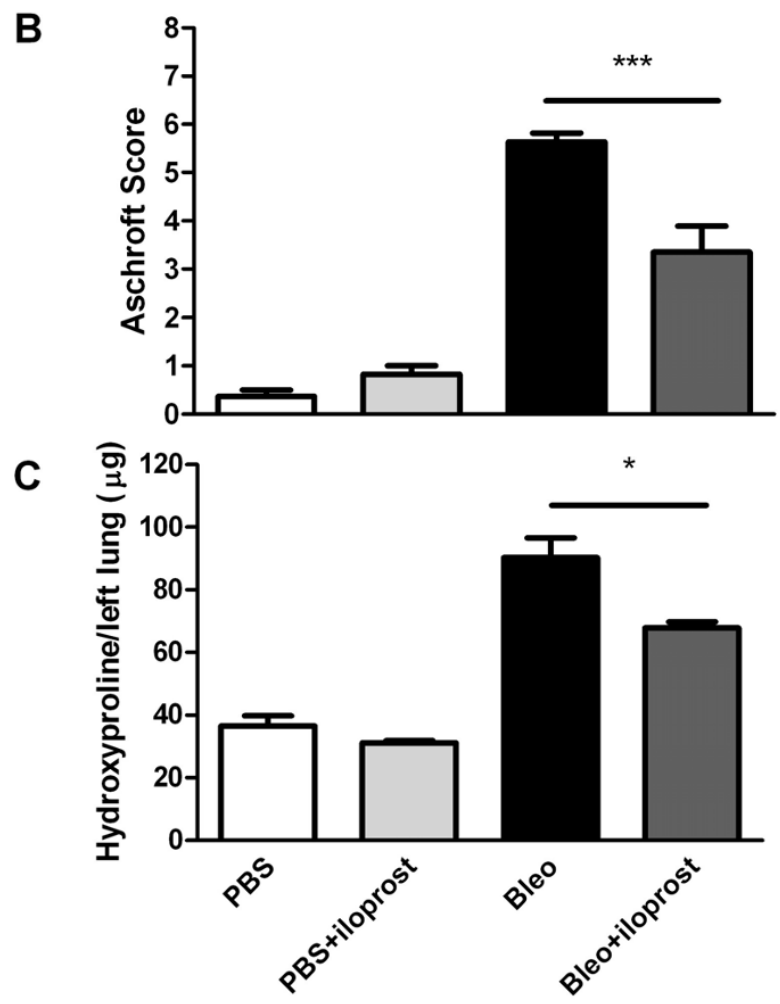

Figure 3 Effect of iloprost on thickened areas of alveolar septum, histopathological scorings and hydroxyproline content in lung tissue. A. Using digital imaging, the thickened areas of alveolar septum in the mice treated with Bleo (no iloprost) was significantly increased compared to those with Bleo+iloprost at day 14. Results are expressed as mean \pm SEM, $n=6-8$ mice per group,

${ }^{* * *} p<0.001$. B, semi-quantitative assessment was performed on day 14 using Aschroft scoring method, a significantly higher score was observed in the mice treated with Bleo (no iloprost) than those treated with Bleo+iloprost. Results are expressed as mean \pm SEM, $n$ $=5-8$ mice per group, ${ }^{* * *} p<0.001$. C, the hydroxyproline content in lung tissue was significantly higher in the mice treated with Bleo (no iloprost) than those treated with Bleo+iloprost. Results are expressed as mean \pm SEM, $n=5-7$ mice per group, ${ }^{*} p<0.05$.
The levels of $\mathrm{PGE}_{2}$ and $\mathrm{LTB}_{4}$ in BAL fluid were significantly higher in the mice treated with bleomycin compared with those treated with PBS. However, we found that $\mathrm{LTB}_{4}$ and $\mathrm{PGE}_{2}$ levels did not differ between the mice treated with bleomycin (no iloprost) and those treated with bleomycin+iloprost (Figure 7A and 7B).

\section{Effect of delayed application of iloprost on bleomycin- induced injury}

When iloprost was given at day 7 post-bleomycin insult, we found that iloprost did not prolong the survival rate, did not improve the body weight loss, did not alleviate infiltration of the inflammatory cells, and did not decrease interstitial collagen accumulation in mice by day 21 post-bleomycin injection.

\section{Discussion}

To our knowledge, this is the first report of an intraperitoneal application of iloprost, a $\mathrm{PGI}_{2}$ analogue, that prevented the pulmonary inflammation and fibrosis induced by bleomycin in mice. A single dose of iloprost prior to bleomycin injection significantly resulted in: (i) reduced mortality and body weight loss; (ii) attenuated infiltration of inflammatory cells into the lung and reduced collagen deposition in pulmonary interstitium; (iii) alleviation of the reduced static compliance and elevated tissue elastance; and (iv) a decreased production of proinflammatory and fibrotic cytokines such as TNF $\alpha$, IL-6 and TGF- $\beta 1$, and an increased release of antifibrotic mediators including IFN $\gamma$ and chemokine CXCL10/IP-10.

Intratracheal instillation of bleomycin induces an acute pneumonitis with inflammatory cells aggregating in the pulmonary interstitium followed by aberrant fibroproliferation and collagen production in mice [22]. Our data showed that the influx of lymphocytes, other than macrophages and neutrophils, into lungs was considerably inhibited by iloprost at day 7 following bleomycin injection. These results suggest that iloprost might exert a direct inhibition of lymphocytic infiltration. Arras and colleagues have demonstrated that B lymphocytes are critical for lung fibrosis through the regulation of $\mathrm{PGE}_{2}$ in mice [23]. Another study performed in ovalbumin-sensitized mice indicated that iloprost had a direct inhibitory effect on lung dendritic cells, but with no effect on T helper 2 lymphocytes [15]. However, we were not able to determine in this current study which subtype of the inflammatory cells, such as natural killer cells and B cells, could be specifically suppressed by iloprost after bleomycin stimulation. 
A

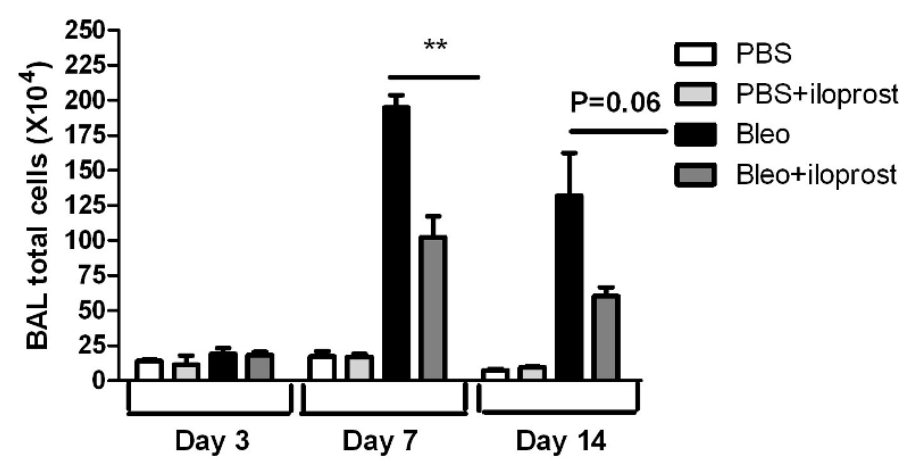

B

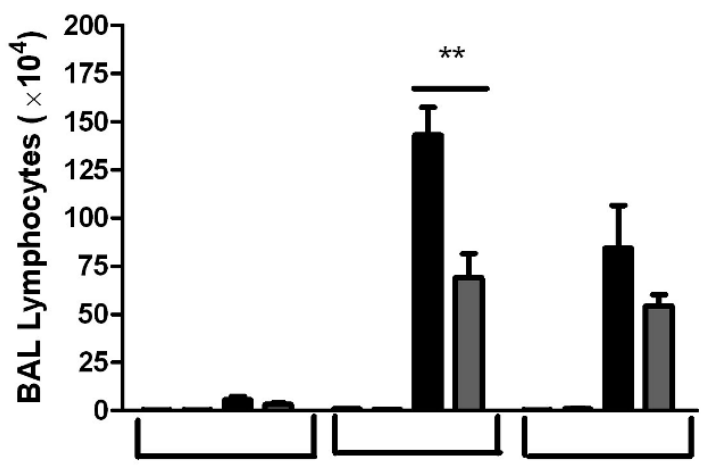

C
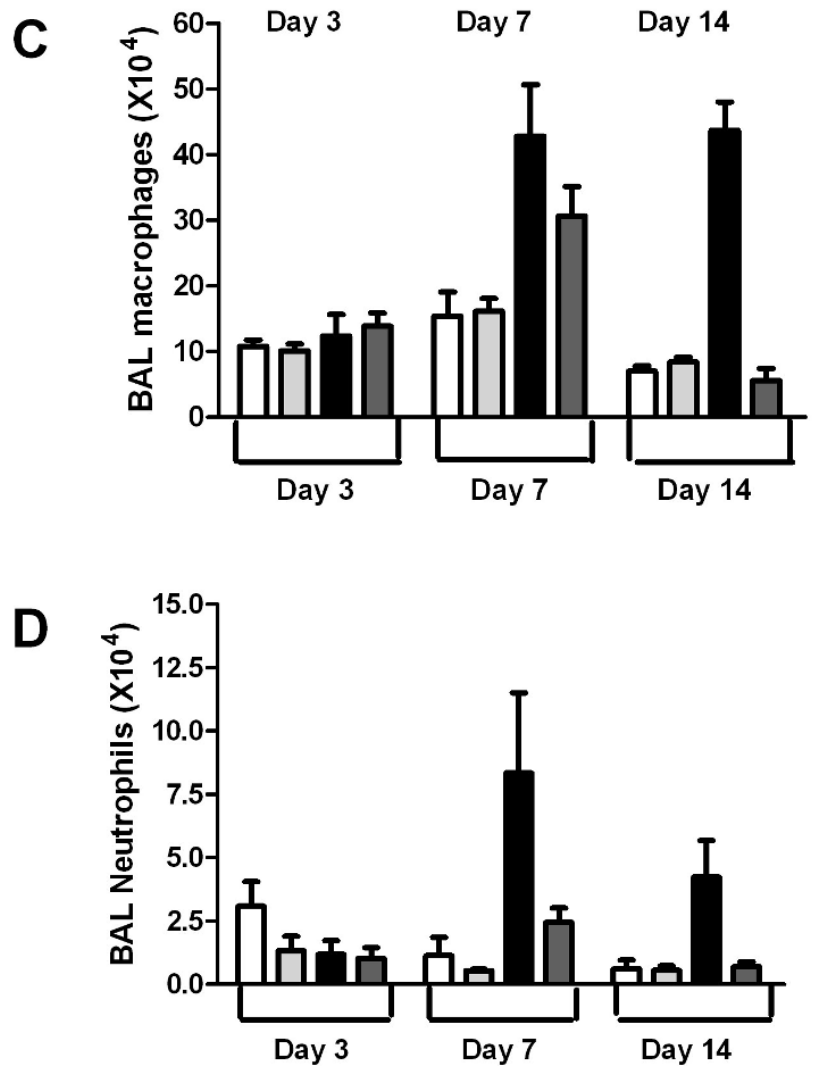

Figure 4 Effect of iloprost on infiltration of inflammatory cells into the airways after bleomycin (Bleo) injection. The mice were injected with $2 \mathrm{mg} / \mathrm{kg}$ of Bleo (no iloprost) or bleo+iloprost, BAL fluid was collected at days 3, 7, and 14 later. The number of inflammatory cells and lymphocytes accumulated in airways was significantly higher in the mice treated with Bleo (no iloprost) than those treated with Bleo+iloprost (A and $B$ ), and there was no significant difference in the number of macrophages and neutrophils in BAL fluid between the mice treated with Bleo (no iloprost) and those treated with Bleo+iloprost (C and D). Results are expressed as mean \pm SEM, $n=5-8$ mice each group, ${ }^{* *} P<0.01$. 


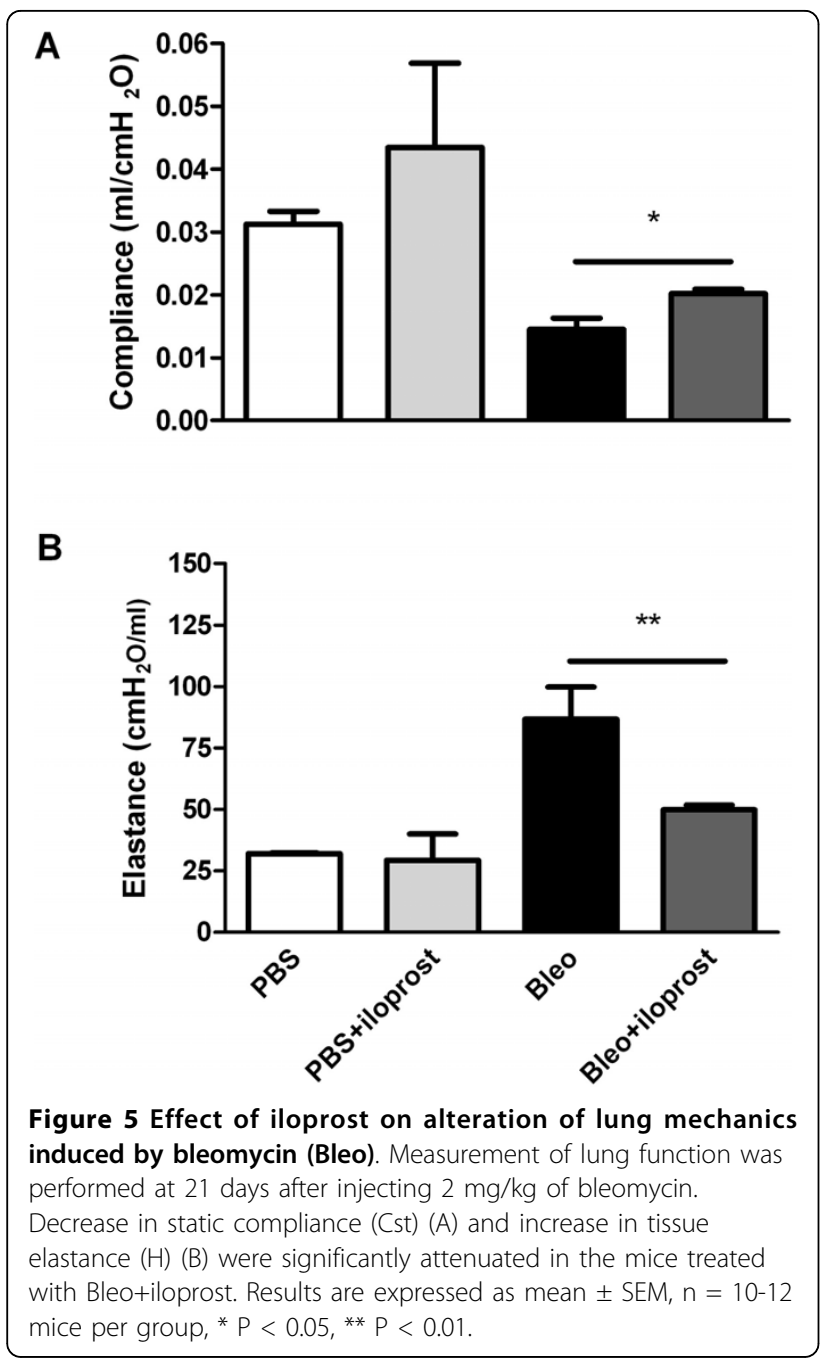

TNF $\alpha$ is considered to be one of the most potent proinflammatory cytokines promoting infiltration of inflammatory cells and proliferation of fibroblasts $[24,25]$. We showed in this study that induction of TNF $\alpha$ mRNA was markedly reduced in the mice treated with bleomycin and iloprost over the time-course of bleomycin-induced lung injury. A previous study reported that $\mathrm{PGI}_{2}$ analogues including iloprost decreased TNF $\alpha$ production by bone marrow-derived dendritic cells [26], and therefore the reduced mRNA expression of TNF $\alpha$ may result from this inhibitory effect of $\mathrm{PGI}_{2}$. IL-6 may modulate pulmonary inflammation as supported by the observation that an increased IL-6 level in BAL fluid was associated with lung fibrosis in human and animal models [27]. In addition, bleomycin-induced lung fibrosis was significantly attenuated in mice lacking the IL-6 gene [28]. In support of these results, our data showed that the IL- 6 level in BAL fluid was elevated in mice 3 days after bleomycin injection; however, such increase was markedly abrogated in iloprost-treated mice. Our data implies that iloprost effectively inhibited the release of IL-6 from the infiltrated inflammatory cells at the initial stage of bleomycin-induced lung injury.

TGF $\beta_{1}$, a fibrogenic cytokine, is expressed in a variety of cells including fibroblasts, macrophages, and epithelial and endothelial cells $[29,30]$. Evidence from human studies and animal models indicates that $\mathrm{TGF} \beta_{1}$, upregulated in the process of fibrosis, plays a pivotal role in mediating the progression of the fibrotic diseases by stimulating fibroblasts to synthesize extracellular matrix proteins $[31,32]$. Sime and colleagues demonstrated that rats overexpressing active TGF $\beta_{1}$ gene developed marked lung fibrosis at day 14 [33]. Consistent with these observations, we observed that $\mathrm{TGF}_{1}$ mRNA and protein was significantly inhibited in the mice treated by iloprost+bleomycin at day 14 . As represented in Figure 6, the increase in IL-6 in BAL fluid at early stage and the elevation of $\mathrm{TGF}_{1}$ in BAL fluid at the late stage of bleomycin-induced pulmonary injury may support previous reports indicating that IL-6 may regulate TGF $\beta_{1}$ signaling [34]. Collectively, these studies indicate that the involvement of $\mathrm{PGI}_{2}$ in preventing lung fibrosis may be due to its direct inhibitory effect on cellular immune response, leading to a reduction in fibrotic mediators.

There is substantial evidence supporting a key role of inhibitory modulators such as the Th1 cytokine, IFN $\gamma$, against fibroblast activation, [35]. A relative deficiency in IFN $\gamma$ mRNA expression was associated with progressive lung fibrosis in IPF patients [36]. Exogenous administration of IFN $\gamma$ has been shown to be critical for limiting lung fibrosis in CXCR3 knockout mice lacking endogenous IFN $\gamma$ [37]. An in vitro study has suggested that IFN $\gamma$ exerts the inhibitory effect on TGF $\beta_{1}$ signaling pathways [38]. In this study, we reported that IFN $\gamma$ levels were markedly higher in the mice treated with iloprost and bleomycin than those treated with bleomycin without iloprost. Interestingly, we first observed that iloprost significantly induced production of IFN $\gamma$ in PBS treated-mice by day 14 in this current study (Figure 6F), indicating that $\mathrm{PGI}_{2}$ is capable of upregulating antifibrotic mediators such as IFN $\gamma$. Additionally, an in vivo study examining the changes of biomarkers in IPF patients indicated that IFN $\gamma$ may modulate fibrosis by down-modulating several pathways relevant to fibrosis, angiogenesis, proliferation, and immunoregulation [39]. The exact regulatory mechanism of $\mathrm{PGI}_{2}$ on IFN $\gamma$ needs further investigation.

CXCL10/IP-10, which is regulated by the antifibrotic factor IFN $\gamma$, has been shown to attenuate bleomycininduced pulmonary fibrosis in mice via inhibition of fibroblast recruitment or of angiogenesis [40]. CXCL10deficient mice displayed increased fibroblast 


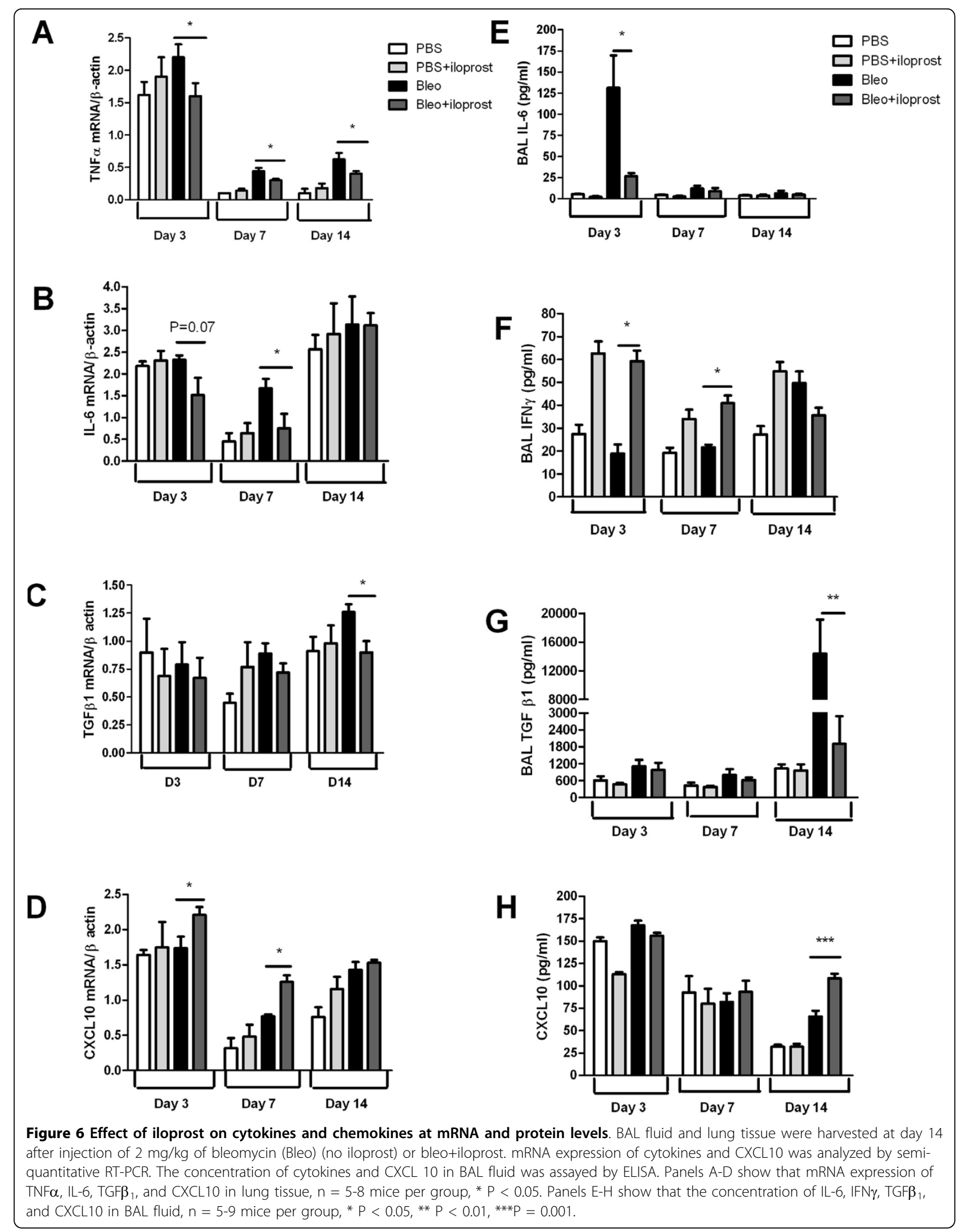




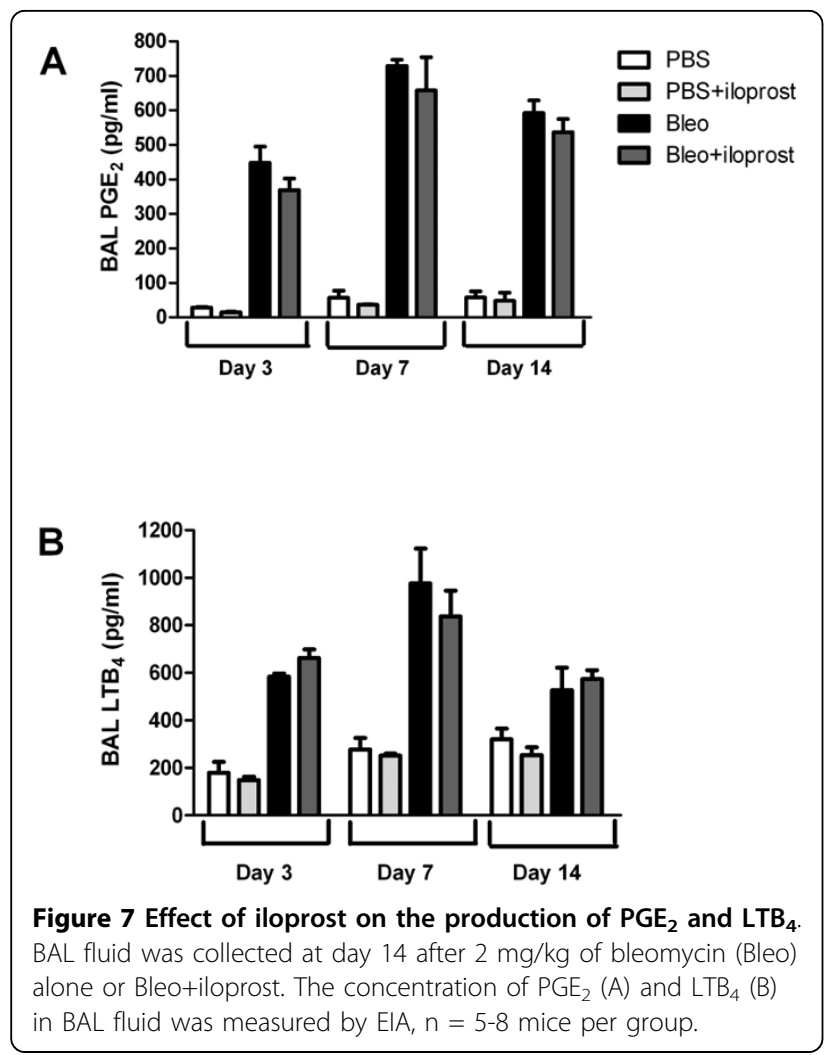

accumulation in the lung after bleomycin exposure. Conversely, transgenic mice overexpressing CXCL10 were less likely to die after bleomycin exposure, associated with a reduction in fibroblast accumulation in the lung [41,42]. Our data demonstrated that there was an increase in CXCL10/IP-10 mRNA level by day 7 and at the protein level at day 14 in the mice treated with iloprost and bleomycin as compared to those treated with bleomycin (no iloprost). We cautiously propose that induction of CXCL10/IP-10 could be secondary to the effect of IFN $\gamma$ which was up-regulated by iloprost in our investigation; however, we cannot rule out other pathways modulating CXCL10/IP-10 in response to bleomycin.

An alternative explanation for both the reduced inflammatory and fibrotic response to bleomycin by iloprost in mice could be eicosanoid imbalance favoring the overproduction of antifibrotic prostaglandins $\left(\mathrm{PGE}_{2}\right)$ and underproduction of fibrotic leukotrienes $\left(\mathrm{LTB}_{4}\right)$. $\mathrm{PGE}_{2}$ is generally recognized as a potent anti-fibrotic agent, and is a major eicosanoid product of alveolar epithelial cells, macrophages, and fibroblasts $[43,44]$. Deficiency in $\mathrm{PGE}_{2}$ has been linked to severity of lung injury and fibrosis $[23,45]$. The production of $\mathrm{PGE}_{2}$ significantly rose in BAL fluid after intratracheal instillation of bleomycin; however, the increase seen in the mice treated with iloprost and bleomycin was similar to those treated with bleomycin (no iloprost) in this current model. Lovgren and coworkers using mice lacking COX-2 and IP demonstrated that $\mathrm{PGE}_{2}$ was not involved in the protection against bleomycin-induced lung fibrosis provided by prostacyclin [13]. Thus, a $\mathrm{PGI}_{2}$-mediated mechanism of preventing lung fibrosis induced by bleomycin is likely to be unrelated to $\mathrm{PGE}_{2}$. Leukotriene $\mathrm{B}_{4}$ functions as a proinflammatory and profibrotic mediator by binding to its specific receptor [6]. Iloprost did not modulate the increase in $\mathrm{LTB}_{4}$ levels in BAL fluid in response to bleomycin, suggesting that iloprost may not affect the lipoxygenase pathway and that iloprost does not limit bleomycin-induced lung pathology by inhibition of $\mathrm{LTB}_{4}$.

In this study, iloprost given at day 7 post-bleomycin, the time point at which pneumonitis and fibrosis are established, failed to decrease mortality and weight loss, to attenuate inflammation and to reverse lung fibrosis in bleomycin-treated mice by day 21 . These data may indicate that iloprost can be preventive, but possibly not therapeutic, for lung fibrotic diseases. It must be emphasized that iloprost was given at one single dose by intraperitoneal route in our study, and therefore additional studies are necessary to test for a reversal effect of iloprost in a time- and dose-dependent fashion, e.g. when given 2-3 days after bleomycin injection and with repeated doses. In addition, whether long-term treatment with iloprost administered via the inhaled route would be beneficial for patients with lung fibrotic diseases should be further investigated.

\section{Conclusions}

In conclusion, these observations provide evidence for a beneficial role of $\mathrm{PGI}_{2}$ in dampening pulmonary inflammation and fibrosis, possibly through inhibiting recruitment of inflammatory cells (predominantly lymphocytes) and decreasing production of TNF $\alpha$, IL- 6 and TGF $\beta 1$, while promoting the generation of IFN $\gamma$ and IFN $\gamma$-targeted CXCL10/IP-10, which are anti-fibroproliferative.

\section{Conflict of interest statement}

The authors declare that they have no competing interests.

\section{Acknowledgements}

This work was supported by grants from Natural Sciences Foundation of China, Beijing Natural Sciences Foundation, Education Ministry of China New Century Excellent Talent, and Open Fund of the Key Laboratory of Human Diseases Comparative Medicine Ministry of Health (No. 30470767, No. 30470768, No. 7072063, NCET 06-0156, ZDS200805) and National Basic Research Program of China (2009CB522106).

\section{Author details}

'Department of Respiratory Diseases, Peking Union Medical College Hospital, Chinese Academy of Medical Sciences \& Peking Union Medical College, Beijing 100730, China. ${ }^{2}$ Department of Pathology, Peking Union Medical 
College Hospital, Chinese Academy of Medical Sciences \& Peking Union Medical College, Beijing 100730, China. ${ }^{3}$ Department of Physiology and Pathophysiology, Peking University Health Sciences Center, Beijing 100191, China. ${ }^{4}$ Department of Respiratory Medicine, Chaoyang Hospital, Capital Medical University, Beijing 100020, China.

\section{Authors' contributions}

$Y Z$ co-supervised and involved in the whole experiment; $Y L$ performed the whole experiment; $W Z$ and $Y X$ carried out the pathological analysis; RX, $L$ and $Z$ G helped and did some experiments; $\mathrm{KH}$ performed the lung function assay; JG designed and co-supervised the experiments, and drafted the manuscript. All authors have read and approve the final manuscript.

Received: 4 December 2009 Accepted: 20 March 2010

Published: 20 March 2010

\section{References}

1. American thoracic society. Idiopathic pulmonary fibrosis: Diagnosis and treatment. International consensus statement. American thoracic society (ats), and the european respiratory society (ers). American journal of respiratory and critical care medicine 2000, 161(2 Pt 1):646-664.

2. Sleijfer S: Bleomycin-induced pneumonitis. Chest 2001, 120(2):617-624.

3. Huang SK, Peters-Golden M: Eicosanoid lipid mediators in fibrotic lung diseases: Ready for prime time? Chest 2008, 133(6):1442-1450.

4. Wardlaw AJ, Hay H, Cromwell O, Collins JV, Kay AB: Leukotrienes, Itc4 and Itb4, in bronchoalveolar lavage in bronchial asthma and other respiratory diseases. The Journal of allergy and clinical immunology 1989, 84(1):19-26.

5. Peters-Golden M, Bailie M, Marshall T, Wilke C, Phan SH, Toews GB, Moore BB: Protection from pulmonary fibrosis in leukotriene-deficient mice. American journal of respiratory and critical care medicine 2002, 165(2):229-235.

6. Izumo T, Kondo M, Nagai A: Effects of a leukotriene b4 receptor antagonist on bleomycin-induced pulmonary fibrosis. Eur Respir J 2009.

7. Huang SK, Wettlaufer SH, Hogaboam CM, Flaherty KR, Martinez FJ, Myers JL, Colby TV, Travis WD, Toews GB, Peters-Golden M: Variable prostaglandin e2 resistance in fibroblasts from patients with usual interstitial pneumonia. American journal of respiratory and critical care medicine 2008, 177(1):66-74.

8. Failla M, Genovese T, Mazzon E, Fruciano M, Fagone E, Gili E, Barera A, La Rosa C, Conte E, Crimi N, et al: 16,16-dimethyl prostaglandin e2 efficacy on prevention and protection from bleomycin-induced lung injury and fibrosis. American journal of respiratory cell and molecular biology 2009, 41(1):50-58.

9. Soberman RJ, Christmas P: Revisiting prostacyclin: New directions in pulmonary fibrosis and inflammation. American journal of physiology 2006, 291(2):L142-143.

10. Cruz-Gervis R, Stecenko AA, Dworski R, Lane KB, Loyd JE, Pierson R, King G, Brigham KL: Altered prostanoid production by fibroblasts cultured from the lungs of human subjects with idiopathic pulmonary fibrosis. Respiratory research 2002, 3:17.

11. Stratton R, Shiwen X, Martini G, Holmes A, Leask A, Haberberger T, Martin GR, Black CM, Abraham D: lloprost suppresses connective tissue growth factor production in fibroblasts and in the skin of scleroderma patients. The Journal of clinical investigation 2001, 108(2):241-250.

12. Kohyama T, Liu X, Kim HJ, Kobayashi T, Ertl RF, Wen FQ, Takizawa H, Rennard SI: Prostacyclin analogs inhibit fibroblast migration. American journal of physiology 2002, 283(2):L428-432.

13. Lovgren AK, Jania LA, Hartney JM, Parsons KK, Audoly LP, Fitzgerald GA, Tilley SL, Koller BH: Cox-2-derived prostacyclin protects against bleomycin-induced pulmonary fibrosis. American journal of physiology 2006, 291(2):L144-156

14. Murakami S, Nagaya N, Itoh T, Kataoka M, Iwase T, Horio T, Miyahara Y, Sakai $Y$, Kangawa $\mathrm{K}$, Kimura H: Prostacyclin agonist with thromboxane synthase inhibitory activity (ono-1301) attenuates bleomycin-induced pulmonary fibrosis in mice. American journal of physiology 2006, 290(1): L59-65.

15. Idzko M, Hammad H, van Nimwegen M, Kool M, Vos N, Hoogsteden HC, Lambrecht BN: Inhaled iloprost suppresses the cardinal features of asthma via inhibition of airway dendritic cell function. The Journal of clinical investigation 2007, 117(2):464-472.
16. Ashcroft T, Simpson JM, Timbrell V: Simple method of estimating severity of pulmonary fibrosis on a numerical scale. Journal of clinical pathology 1988, 41(4):467-470.

17. Beller TC, Friend DS, Maekawa A, Lam BK, Austen KF, Kanaoka Y: Cysteinyl leukotriene 1 receptor controls the severity of chronic pulmonary inflammation and fibrosis. Proceedings of the National Academy of Sciences of the United States of America 2004, 101(9):3047-3052.

18. Card JW, Voltz JW, Carey MA, Bradbury JA, Degraff LM, Lih FB, Bonner JC, Morgan DL, Flake GP, Zeldin DC: Cyclooxygenase-2 deficiency exacerbates bleomycin-induced lung dysfunction but not fibrosis. American journal of respiratory cell and molecular biology 2007, 37(3):300-308.

19. Nagase T, Uozumi N, Ishii S, Kita Y, Yamamoto H, Ohga E, Ouchi $Y$, Shimizu T: A pivotal role of cytosolic phospholipase a(2) in bleomycininduced pulmonary fibrosis. Nature medicine 2002, 8(5):480-484.

20. Nie L, Xiang R, Zhou W, Lu B, Cheng D, Gao J: Attenuation of acute lung inflammation induced by cigarette smoke in cxcr3 knockout mice. Respiratory research 2008, 9:82.

21. Moore BB, Paine R, Christensen PJ, Moore TA, Sitterding S, Ngan R, Wilke CA, Kuziel WA, Toews GB: Protection from pulmonary fibrosis in the absence of ccr2 signaling. J Immunol 2001, 167(8):4368-4377.

22. Moore BB, Hogaboam CM: Murine models of pulmonary fibrosis. American journal of physiology 2008, 294(2):L152-160.

23. Arras M, Louahed J, Simoen $V$, Barbarin V, Misson $P$, Brule van den S, Delos M, Knoops L, Renauld JC, Lison D, et al: B lymphocytes are critical for lung fibrosis control and prostaglandin e2 regulation in il-9 transgenic mice. American journal of respiratory cell and molecular biology 2006, 34(5):573-580.

24. Piguet PF, Collart MA, Grau GE, Kapanci Y, Vassalli P: Tumor necrosis factor/ cachectin plays a key role in bleomycin-induced pneumopathy and fibrosis. The Journal of experimental medicine 1989, 170(3):655-663.

25. Piguet PF, Collart MA, Grau GE, Sappino AP, Vassalli P: Requirement of tumour necrosis factor for development of silica-induced pulmonary fibrosis. Nature 1990, 344(6263):245-247.

26. Zhou W, Hashimoto K, Goleniewska K, O'Neal JF, Ji S, Blackwell TS, Fitzgerald GA, Egan KM, Geraci MW, Peebles RS Jr: Prostaglandin i2 analogs inhibit proinflammatory cytokine production and $t$ cell stimulatory function of dendritic cells. J Immunol 2007, 178(2):702-710.

27. Yoshida M, Sakuma J, Hayashi S, Abe K, Saito I, Harada S, Sakatani M, Yamamoto S, Matsumoto N, Kaneda Y, et al: A histologically distinctive interstitial pneumonia induced by overexpression of the interleukin 6 , transforming growth factor beta 1 , or platelet-derived growth factor $b$ gene. Proceedings of the National Academy of Sciences of the United States of America 1995, 92(21):9570-9574.

28. Saito F, Tasaka S, Inoue K, Miyamoto K, Nakano Y, Ogawa Y, Yamada W, Shiraishi $Y$, Hasegawa N, Fujishima S, et al: Role of interleukin-6 in bleomycin-induced lung inflammatory changes in mice. American journal of respiratory cell and molecular biology 2008, 38(5):566-571.

29. Lee CG, Kang HR, Homer RJ, Chupp G, Elias JA: Transgenic modeling of transforming growth factor-beta(1): Role of apoptosis in fibrosis and alveolar remodeling. Proceedings of the American Thoracic Society 2006, 3(5):418-423.

30. Bartram U, Speer CP: The role of transforming growth factor beta in lung development and disease. Chest 2004, 125(2):754-765.

31. Bergeron A, Soler $P$, Kambouchner M, Loiseau P, Milleron B, Valeyre D, Hance AJ, Tazi A: Cytokine profiles in idiopathic pulmonary fibrosis suggest an important role for tgf-beta and il-10. Eur Respir J 2003, 22(1):69-76.

32. Khalil N, O'Connor RN, Flanders KC, Unruh H: Tgf-beta 1, but not tgf-beta 2 or tgf-beta 3, is differentially present in epithelial cells of advanced pulmonary fibrosis: An immunohistochemical study. American journal of respiratory cell and molecular biology 1996, 14(2):131-138.

33. Sime PJ, Xing Z, Graham FL, Csaky KG, Gauldie J: Adenovector-mediated gene transfer of active transforming growth factor-beta1 induces prolonged severe fibrosis in rat lung. The Journal of clinical investigation 1997, 100(4):768-776

34. Zhang $X \mathrm{~L}$, Topley $\mathrm{N}$, Ito $\mathrm{T}$, Phillips A: Interleukin-6 regulation of transforming growth factor (tgf)-beta receptor compartmentalization and turnover enhances tgf-beta1 signaling. The Journal of biological chemistry 2005, 280(13):12239-12245.

35. Segel MJ, Izbicki G, Cohen PY, Or R, Christensen TG, Wallach-Dayan SB, Breuer R: Role of interferon-gamma in the evolution of murine 
bleomycin lung fibrosis. American journal of physiology 2003, 285(6): L1255-1262.

36. Ziesche R, Hofbauer E, Wittmann K, Petkov V, Block LH: A preliminary study of long-term treatment with interferon gamma-1b and low-dose prednisolone in patients with idiopathic pulmonary fibrosis. The New England journal of medicine 1999, 341(17):1264-1269.

37. Jiang D, Liang J, Hodge J, Lu B, Zhu Z, Yu S, Fan J, Gao Y, Yin Z, Homer R, et al: Regulation of pulmonary fibrosis by chemokine receptor $\mathrm{cxcr} 3$. The Journal of clinical investigation 2004, 114(2):291-299.

38. Ulloa L, Doody J, Massague J: Inhibition of transforming growth factorbeta/smad signalling by the interferon-gamma/stat pathway. Nature 1999, 397(6721):710-713.

39. Strieter RM, Starko KM, Enelow Rl, Noth I, Valentine VG: Effects of interferon-gamma $1 \mathrm{~b}$ on biomarker expression in patients with idiopathic pulmonary fibrosis. American journal of respiratory and critical care medicine 2004, 170(2):133-140

40. Strieter RM, Gomperts BN, Keane MP: The role of cxc chemokines in pulmonary fibrosis. The Journal of clinical investigation 2007, 117(3):549-556.

41. Tager AM, Kradin RL, LaCamera P, Bercury SD, Campanella GS, Leary CP, Polosukhin V, Zhao LH, Sakamoto H, Blackwell TS, et al: Inhibition of pulmonary fibrosis by the chemokine ip-10/cxcl10. American journal of respiratory cell and molecular biology 2004, 31(4):395-404.

42. Keane MP, Belperio JA, Arenberg DA, Burdick MD, Xu ZJ, Xue YY, Strieter RM: Ifn-gamma-inducible protein-10 attenuates bleomycininduced pulmonary fibrosis via inhibition of angiogenesis. J Immunol 1999, 163(10):5686-5692.

43. Wilborn J, Crofford LJ, Burdick MD, Kunkel SL, Strieter RM, Peters-Golden M: Cultured lung fibroblasts isolated from patients with idiopathic pulmonary fibrosis have a diminished capacity to synthesize prostaglandin e2 and to express cyclooxygenase-2. The Journal of clinical investigation 1995, 95(4):1861-1868.

44. Charbeneau RP, Christensen PJ, Chrisman CJ, Paine R, Toews GB, PetersGolden M, Moore BB: Impaired synthesis of prostaglandin e2 by lung fibroblasts and alveolar epithelial cells from gm-csf-/- mice: Implications for fibroproliferation. American journal of physiology 2003, 284(6): L1103-1111.

45. Hodges RJ, Jenkins RG, Wheeler-Jones $\mathrm{CP}$, Copeman DM, Bottoms SE, Bellingan GJ, Nanthakumar CB, Laurent GJ, Hart SL, Foster ML, et al: Severity of lung injury in cyclooxygenase-2-deficient mice is dependent on reduced prostaglandin e(2) production. The American journal of pathology 2004, 165(5):1663-1676.

doi:10.1186/1465-9921-11-34

Cite this article as: Zhu et al:: A prostacyclin analogue, iloprost, protects from bleomycin-induced pulmonary fibrosis in mice. Respiratory Research 2010 11:34.

\section{Submit your next manuscript to BioMed Central and take full advantage of:}

- Convenient online submission

- Thorough peer review

- No space constraints or color figure charges

- Immediate publication on acceptance

- Inclusion in PubMed, CAS, Scopus and Google Scholar

- Research which is freely available for redistribution

Submit your manuscript at www.biomedcentral.com/submit
Biomed Central 